\title{
The (In)visible Romá mobility
}

Norma Baldino ${ }^{1}$

\begin{abstract}
The Roma issue is a complex, multifaced phenomenon. Existing research on Roma communities in Italy bas examined the ways in which recent political debate and policy initiatives have succeeded in reframing the Roma issue exclusively in terms of emergency and public security (Maneri 2018, Piasere 2015, Solimene 2014, Tosi Cambini 2012). Few empirical studies, however, have analysed how the social construction of the Gypsy Problem in Italy is reflected in everyday life. Based on ethnographic research conducted in Cagliari from 2010 until today, this article analyses and discusses how a Xoraxané Romá community's everyday life changed after the eviction from the nomad camp where they had lived for 30 years. Focusing on cultural processes, three main issues are explored: the "sense of place" and the spatially representation of their identity in the nomad camp; the effects of housing policies promoted in Cagliari; the relation between antigypsism and Romá mobility.
\end{abstract}

Keywords: Roma people; social exclusion; stigma; identity

\section{Introduction}

Italy is the European country with the highest level of anti-Gypsism (Pew Research Centre 2014, Meneghini and Fattori 2016). Institutions and the collective imagination portray Roma in Italy as marginal and dangerous people, who need to be assisted or controlled, re-educated and confined as a threat to public safety. Particularly since 2008, when "the gypsy problem" started to emerge in Italy and Europe, scholars have discussed strong discrimination against Romani groups and their treatment in terms of alleged threats to public order, public health, social security systems and national security (Aradau 2015, Parker 2012, Van Baar 2011). Their disadvantages originate in persistent categorisation processes that label and dehumanize them (Nicolae 2006). Recent literature examines the effects on Roma communities of the ways in which

\footnotetext{
${ }^{1}$ Norma Baldino, University of Cagliari, Italy. E-mail: normabaldino@tiscali.it.
} 


\section{The (In)visible Romá mobility}

distinct categorisations are used in different contexts and by different social agents (Pontrandolfo and Solimene 2018; Grill 2017). A debate on the construction of Gypsy - Nomad - Roma categorisation has developed as a particularly stimulating perspective when addressing the power of labelling different Others (Pontrandolfo 2018). As Nomads, consequently placeless, uncivilized, exotic and continually mobile, they are seen as an illicit presence and threat to the maintenance of national borders (Williams 2011). As Roma or Gypsies, they are regarded as backward, inferior, dangerous, criminal and, thus, as associated with a deviation from what has been rendered normal, regular, natural (Van Baar 2015b). Discrimination is the result in many aspects of their lives, such as, for example, access to housing, poor housing conditions, segregation and forced evictions (see FRA 2009). Relegated to the margins of the legal state (Agamben 2005), Roma are also turned into non-persons in social terms (Dal Lago 2004). Labels and repressive policies focus on the concentration of Roma in camps and other housing solutions referring to the biopolitics of otherness (Fassin 2001). Italy particularly stands out for adopting segregatory housing policies by setting up so-called 'nomad camps', so much so that it was defined as 'campland' in one historic report which denounced these policies as a violation of human rights (ERRC 2000). As many scholars have pointed out, Italian 'nomad camps' represented spaces of social imposition (Saletti Salza 2003). In particular, Sigona has emphasized the ambiguity embedded in policy for solving the 'gypsy problem' as well as that ingrained in the regional laws for 'safeguarding Gypsy/Romani/nomadic culture(s)', in which he has analysed the role of the concept culture (Sigona 2011). He proposed the concept of 'campzenship' to capture the specific and situated form of membership produced in and by the camp, the complex and ambivalent relationship of its inhabitants with the camp, and the ways the camp shapes the relationship of its inhabitants with the state and their capacity and modes of being political (Sigona 2014).

In assigning spaces for Gypsies, Nomads or Roma, policies are usually accompanied by production and diffusion of anti-gypsism (Piasere 2005). According to processes that Mary Douglas (1991) defines as blaming, anti-gypsism consists in the mechanism by which a society blames and defines responsibilities in a continuous process of redefining its borders. Therefore, in a large anthropological framework of heteroconstructed gypsy groups, Piasere (2015) speaks about anti-gypsism within the classical concept of racism as sustained by Taguieff (1987). In this scenario, Roma react to labelling processes and the adequate recognition of one's difference becomes a fundamental requirement for the full development of oneself (Colombo 2007). Even if discriminating and a source of exclusion, difference becomes one of the few hooks 
on which to fix one's existence. In affirming their difference, marginal individuals and groups often find themselves forced to assemble images of themselves obtained from "waste" elements (Bauman 2005). There is little doubt that the categorization and racialization of Roma can be considered as one of the outcomes of the mobilisation and proliferation of different identity groups and their struggles for recognition (Taylor 1994). While practices of deportation have led to the forced mobility of Roma and their contained circulation at a European level, those of racialized ghettoization, due to the eviction and segregation, have resulted in situations that come close to their forced immobility and restricted production of locality (Appadurai 1996).

While the majority of research carried out to date has brought to light the more violent aspects of 'nomad camp' governmentality, few have focused on the practical impacts of labels on Roma everyday life in terms of identity and self-representations. The aim of this paper is to analyse the connection between local anti-gypsism and the practices of representation and recognition of a Xoraxané Romá family in space. It focuses precisely on the connection between anti-gypsism and Romá mobility as recognition in space. It examines how the living spaces that are attributed by non-Roma, based on housing inclusion policies, represent for Romá both adaptation and definition of their identity. ${ }^{2}$ The first pages reconstruct the history of the Xoraxane community in Cagliari; later, the focus is on three key issues: the link between processes of recognition in the nomad camp space before, and in a house after the eviction of the camp then and, finally, the visibility/invisibility of their mobility as a result of subsequent inclusion policies.

\section{Xoraxané Romá in Cagliari}

This article draws from materials collected during my ethnographic fieldwork with an extended family of Bosnian Xoraxané Romá carried out between January 2010 and November 2015 in Cagliari, the capital of the island of Sardinia in the Mediterranean Sea. The ethnographic experience was built day after day, according to the unexpected discoveries of the Serentipity (Merton 1949) that marked and oriented the fieldwork. Building trust with Romá has been a constant guide during my long ethnographic journey to avoid some obstacles. From my first observations, I understood that gender differences and my youth would not have helped my movements and interactions with Romá. Difficulties guided my choices: I started interacting with children, who accepted me for helping them with their homework. In this way, Romá daily recognised my presence in the nomad camp allowing me to get closer first to young people and then

2 The distinction between Roma and Romà is intended: Roma means "roma people”; Romà refers to the specific Xoraxané group. 


\section{The (In)visible Romá mobility}

to women. An interesting and stimulating relationship was born with women: they constantly observed me, but, at the same time, gave me "true" life advice as a gagè. They taught me to cook, to make coffee according to their traditions and they gave me advice on choosing a future husband. Some months after my first entries, I managed not to be perceived as an intrusion or a danger by men. Men started to interact with me as a bridge with the gagè society: I read the post delivered to the camp, court sentences, or newspaper articles concerning the future of the nomad camp. Time was crucial to develop a privileged relationship based on trust with Rubi, my key interlocutor ${ }^{3}$. When I met him for the first time, Rubi was 17 years old and lived alone in a caravan located next to his father. He was not married; he dropped out of school early before graduating from middle school. His curiosity together with my perseverance made it possible to build a relationship according to which, for the first time in my fieldwork, I (a gagè) was the teacher and he (a Româ) the student. We used to carve out spaces every day to study from my old school texts that I gave him. He graduated from school and this goal was a sort of cultural exchange that gave our relationship such confidence that led me to establish a link with him and then, after 3 years, with his wife. During this period, I lived immersed in Romá everyday life. I experienced the everyday routine in a nomad camp before and then in houses: this gave me the opportunity to observe the changes in the management of domestic spaces. I had the chance to observe the interactions of the Romá in public spaces too, such as their movements and mobility in the metropolitan area. The intensity of ethnographic immersion, granted me access to their Mangel (begging) practices in the Municipal Market and allowed me to be accepted into spaces of intimacy and to understand aspects of Romani life usually stigmatized and uncharted.

My first entrance in the nomad camp, situated on the periphery of Cagliari, dates back to January 2010. Since then, I have been learning about the Romani world from literature developed on "contempt urban planning" of nomad camps (Brunello 1996) and I have been following the vicissitudes of the first Roma family who lived in Cagliari. I knew that the first so-called gypsy groups had arrived in Cagliari in the late seventies from Bosnia, Montenegro and Krajina, and that they settled in several illegal settlements at the entrance of the city, more precisely in Cornalias, San Simeone, Simeto, and the streets of San Paolo. The first spontaneous camps were something different from the current formal ones: Roma who lived there were mostly foreigners or stateless people, generally engaged in itinerant activities, both annually and seasonally. Local administration and enforcement agencies did not recognise their

${ }^{3}$ As of this moment, all proper names reported in the paper are invented in compliance with the research ethical code. 
right to housing. The largest and visible group camped in San Paolo area, near to the city harbour, immediately became a problem of urban decorum due to their proximity to the city gateway. In 1995, the Regional Administration built a regulated camp along the state road that circumscribes the metropolitan area. The camp, called 554 by the name of the road, was based on the Regional Law no. 9 of 1988, known as The Tiziana law (from the name of a girl who died in via San Paolo from bronchopneumonia). The recognition of nomadism as a Romani trait culture was the key to the law: the construction of the camp to control the Roma was justified by protecting the right to be a nomad. Within a few months, the 800 people who had been identified at the inauguration of the camp had been reduced to 400 . Since then, the Roma population living in Cagliari has changed considerably: births have increased as well as an influx of foreign Roma from ex-Yugoslavia and Romania. In the meantime, those based here began to acquire Italian citizenship. Life in a formal camp did not improve compared to informal spaces: a legislative guarantee was not enough to change the living conditions of Roma. It was a 9000 square-meter open-air dump, without services or connections to the city centre. Formally, the camp had bathrooms with shared toilets and showers, a multi-purpose centre, an artisans' workshop and an exhibition room. In reality, these spaces were never used because they were immediately destroyed by the Roma residents. They lived in self-built shacks and caravans. Quarrels were frequent. The area was divided into two parts: one for the presumably settled Gypsies (later occupied by the Bosnian Muslim families) and the other for the nomads who transit (occupied by the Serbian Orthodox families). This division separated the two extended families who had no economic or parental ties. Their cultural diversity was never considered by the municipal administration that forced families to cohabit.

My ethnographic field work ${ }^{4}$ is conducted with the homogeneous group of Bosnian Muslim families. They have neither a traveling tradition nor a tendency to travel due to daily life in the camp: leaving it would have meant losing the right to housing. Today, about half of the Roma evicted from the camp and still living in the Cagliari area were born in Cagliari; they have been recognized as Italian citizens at the age of $18^{5}$. This is a detail that should not be underestimated as it reinforces both the idea of settling and territorial and cultural isolation. The rest have regular residence permits, as well as those who have arrived from Romania in the past ten years and are living in

\footnotetext{
${ }^{4}$ After my doctoral dissertation and a fieldwork experience in Spain until 2017, I returned to Cagliari having the opportunity to visit Roma and follow their latest vicissitudes.

${ }^{5}$ The law of 5 February 1992, n. 91 regulates the acquisition of citizenship by birth and residence in Italy and at the age of 18. The child of foreign parents, born and raised in Italy, at the age of eighteen can become an Italian citizen.
} 
informal camps. Some are still undocumented and unregistered. After more than seven years from the activation of the municipal inclusion plan, the subsistence of the Roma families of Cagliari is still linked to an economy based essentially on the use of welfare resources (request for help from voluntary associations, service municipal social, churches), on occasional and underpaid work or on irregular activities.

\section{The nomad camp: space and Romá identity}

In anthropological research on Gypsies in which kinship is mentioned, various groups have been described some as patrilinear, others as matrilineal or matriarchal. Cozannet focuses on the social order of the Gypsies: she constantly stresses that they are organized matrilinearly (Cozannet 1977). Others find traces of the matriarchy (Scotti 1978). The success of this idea is due to the importance of the elderly woman among the Roma, and also to the influence of research by Thompson (1923), who dealt with the problem of matrilinearity among the Roma people. Piasere offers us a rereading of the concepts used by the English anthropologist and shows that the Roma matrilinearity has not been proven. In contrast to the matrilinearity mentioned by Cozannet and influenced by Thompson, Liègeois and Piasere affirm that, in general, the Roma are patrilinear (Liègeois 1987 and Piasere 1991).

This article is not intended to explain the origins of the Roma Xoraxanè kinship system, but to analyse the meaning of space within the nomad camp. Considering proximity as a cohesion factor of a group (Fabietti 2004), the observation of space focuses on the Rubi's extended family of residence; that is the group formed by its kin with whom it shares the residence. In the nomad camp of Cagliari, this is possible thanks to the rule of patrilocality. The stories of the Romá and the careful observation of space show that a new couple generally settles with the groom's parents in the first years of marriage. Due to the limited space of the shacks, the Romá buy a caravan that is always placed close to that of the father-in-law. In this way, both family groups can share the same external space. Patrilocality is temporary and exists only in relation to the extended family: after a certain period of time - which often coincides with the birth of the first child - the couple moves away to give space to a younger brother who gets married. The groom's parents help raising the new family, even with a financial support.

The typical extended family of residence is composed of elderly parents, the conjugal family of the youngest son and all other unmarried children as the figure shows with the families 1-6. 
Figure 1.
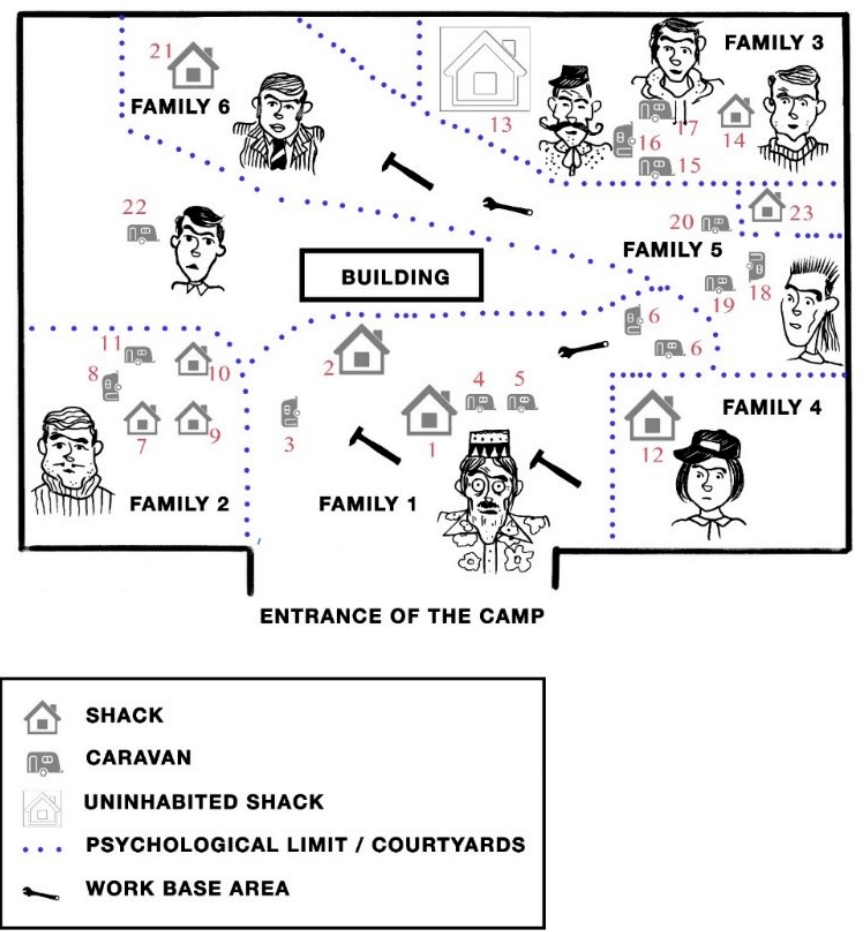

Kinship relationships are visible from the spatial arrangement of homes. Reading the space was an attempt to visualize the mutual kinship ties of the members who lived in the camp of 554. As the figure shows, the trend was to arrange the houses so that the family group shares the same external area. Xoraxanè of Cagliari are essentially traders who prefer to exchange metals; they work in families with whom they share the same work yards. The division of the six nuclear families in the figure indicates both the parental proximity and work associations through the construction of courtyards, often circularly delimited by houses. Those courtyards serve as a work base, to accumulate metals as a kind of workshop. The arrangement of the caravans is a metaphor for the closeness of families (Zatta 1988) and the use of space expresses the Romá conception of individual kinship relationships. Distances between families reflect the structural ties of kinship. The distance between parents and children and between siblings is minimal in sharing a single courtyard. As observed by Piasere for other Xoraxane Roma groups (Piasere 1999), also for Rubi's extended family there is a sort of hierarchical order in the bonds of proximity that is also respected in the spatial arrangement. First of all, Rubi considers the relationships with his nuclear family; the relationships with the relatives, from the parents to the more distant ones are more 
important than the relationships with the non-relatives (these are marginal ties as regards the sharing of space in the nomad camp). The Bosnian family, in fact, who had no blood relations with the Serbian Roma family, lived on the opposite side of the camp.

"Family 1" is the extended family of Serif and Zehera composed of all the houses numbered 1 to 6 in the figure. The shack n. 1 is Serif's, the eldest and the most prestigious man of the group. This is spatially represented by the position of the house at the entrance of the camp: it reflects in the public eye the power to control all the movements inside and outside the camp. The other shacks and caravans $(2,3,4,5)$ are inhabited by unmarried children and grandchildren. Caravan no. 3 deserves special attention: It is inhabited by a daughter of Serif married to a son of Mezo ("family 2". The position of the caravan 3, in the centre between "family 1" and "family 2" (nn 711), reflects the kinship ties between the brothers Mezo and Serif. Mezo, occupies the largest shack (n.7), which he shares with his wife and three children. Two daughters, over twenty, live in caravan n.8, and have decided not to marry: it is an exceptional womanhood. What is more, "family 2", like "family 1", arranged the houses in an almost circular shape, to delimit and distinguish themselves from the others, even if their relationships are excellent. Spaces are not marked by a physical object but by a psychological limit not visible to camp's outsiders. There is an interruption of the rule of patrilocality given by the presence of Mezo's daughter, Tania, who is married to Nicola with whom she lives in caravan n. 11: Nicola's parents remained in Bosnia. "Family 3" (nn 14-17) is composed by Duliano's nuclear family. Duliano's shack (n. 14) is located next to his father Fadil (n.13), temporarily uninhabited due to his expulsion from the camp after a violent quarrel. Duliano, expecting his eleventh child, has 10 children, living between caravans 15 and 16. The eldest son, Rubi, lives alone in caravan n.17, in view of a coming marriage. "Family 4" is made up by Sandra (Duliano's only sister still present in the camp) who lives in hut n. 12, with her husband Marco and their six children. Between "family 1" and "famlily 3" there are the Munib's caravans ("Family 5", nn. 18-20). Munib (n.18) is cousin of Duliano (n.14) and brother of Walter (n. 21). The shacks of the two brothers ("family 5" and "family 6") are distant due to the availability of pitches at the time of Walter wedding in 2000 with Monica, who moved from Alghero nomad camp. In this case, the distance is only physical due to the presence of buildings in the centre of the campsite, as figure shows. Nevertheless, the sharing of the courtyard and the workspaces demonstrate a close and trusting bond. Shack n.23 is inhabited by Disco (son of Mezo) and his wife: its position near family 5 reflects a solid work relationship. Caravan no. 22 is inhabited by Mamile: it is the only case of absence of family ties in the camp, as highlighted by 
its position. His family came from Bosnia during the ' 90 s but left the camp in 1995, when it was constructed.

Each inhabited space, caravan or shack represents a home unit in which only one married couple can live; I have never noticed two couples living in one house. The relationship between husband and wife is of the utmost confidentiality. Sexual relations are considered impure: they do not talk about them casually, not even about virginity, considered an essential condition for the bride. Speaking about virginity, Svetlana told me that it means: "Ciéjahà! Pure! Never touched. Saints! Like the Madonna. Because it is a dishonour to lose your virginity, so you become impure!"6.

The residence factor prevails over the offspring. The formation of hierarchical groups is impossible: one family cannot dominate another. The hierarchy exists only within the family group, where the husband/father exercises full authority over his children and his wife; brothers or sisters; the sisters-in-law on the daughter-in-law, the motherin-law on the daughter-in-law. As an institution within Roma society, the mother-inlaw has a lot of power and authority: she can scold her daughter-in-law or even her son-in-law. Svetlana, in fact, told me: "It is always the mother-in-law who gives you the examples, gives you the right tips. On the contrary, a man cannot do it, he cannot advise you. The woman is the bearer of advice, because she herself has been a daughter-in-law, and she can say how things can be improved".

But outside the family sphere, all Roma are equal.

\section{Life in the apartment: the housing inclusion project}

The inhabitants were evicted from the camp in 2012, as part of a three-year (20122015) municipal project to improve housing, education and access to health services. Its aim was to increase the lives of the Roma by overcoming social exclusion and campsite politics. The housing strategy consisted of renting houses for the Roma through the support of Caritas (an Italian charity organisation), which acted as a guarantor and mediator with the tenants. However, from the beginning, the main problems were: finding large available homes to accommodate very large families, facing strong stereotypes and the lack of trust in the Roma community. This caused a territorial dispersion of all Roma and the fragmentation of family's space hierarchy.

It was not easy to find a home for Rubi and Svetlana: they spent the first period of co-existence in a peripheral area of Monserrato, in the abusive shack of Rubi's father

\footnotetext{
${ }^{6}$ From now on, I faithfully report the translation of the field notes, aware of any grammatical errors, in order not to lose the truthfulness of the ethnographic stories.
} 
together with his 12 brothers. They had no water, electricity, toilets or heating sources: "A bottle of water was enough for us to wash all the dishes and rinse them. There was no water and light because it was disconnected as we did not have the money: the Municipality paid it for a year, but when it expired no one notified us and therefore they disconnected everything "- Svetlana told me - "We preferred to buy a pack of water bottles a day to wash ourselves, walking from the supermarket to the campsite, which was very far away. But at least it was a little better, because I didn't live like this with my parents, I wasn't used to it". Jenni was born here in 2013: her birth pushed the young couple to look for a more dignified housing solution, also out of fear that social services took her to foster care. They decided to adhere to the housing inclusion project promoted by the Municipality. While waiting to find an apartment, they moved in with a friend in Cagliari, but coexistence proved to be unsuccessful due to some difficulties. For a short period (between October and December 2014) Rubi, Svetlana and Jenni returned to Rubi's father, who had already moved illegally to another peripheral area of the Cagliari hinterland called San Lorenzo. All the places where they have decided to move and settle with their caravan are close to the 554 ringroad. This appears interesting if linked to what observed by Solimine about Cergarja from Bosnia (Solimene 2013): the Xoraxané Romá marks an identity displayed with pride based on "living roaming" as well. Roaming means living outside the authorised houses for nomads and moving between empty urban spaces scarcely controlled by the authorities (Solimene 2013). The housing discomfort and the poor sanitary conditions led social services to advise Rubi to leave the shack without mentioning it to his father. So, Rubi's nuclear family moved to Cagliari, while his father lost the power of parental authority over his children. After regulating residence permits and applying for Italian citizenship, Rubi and Svetlana took possession of an apartment in the historic centre of Villanova in December 2014. The intention of the couple was to regularize their union through a civil marriage, which, in fact, was impossible due to the absence of missing documents, which had been left in Bosnia. Cohabitation in this apartment lasted only 4 months: the continuous racist complaints of the neighbours pushed the couple to look for a new home. They preferred a peripheral area "less visible to people from Cagliari and the shops". The director of Caritas confirmed that "unfortunately for the prejudices that still exist, the neighbours recognised that they were Roma because of the skirts they wore and they pressured them to leave the bouse".

Finally, in April 2015, they found accommodation in an apartment in Is Mirrionis, one of the most densely populated neighbourhoods in Cagliari. Unlike the nomad camp, where the rule of patrilocality and virilocality limited the spatial disposition of housing, in an apartment the local unit tends to be made up of people linked to each other by 
the bond of marriage. For the first time, they dealt with a condominium and a dimension of sharing spaces and rules that were completely different from both the nomad camp and from previous housing solutions. For Rubi, living in a popular neighbourhood meant immersing himself in a subcultural dimension already known: "here I am better, people are much kinder and it is easy to make friends with neighbours". But for Svetlana, moving, meant following the choices and authority of her husband: "the centre is much better, I am very well in the centre, and then I like the house very much, but if he wants to leave, he wants to go and live there. And what can I do? Go there?"7 - she said. The proximity of the apartment to the hospital was a not insignificant factor in choosing the new home. They appreciated life in the apartment but regretted leaving the campsite for the opportunity to spend free time with the entire extended family. They liked the new private dimension, the ability to manage domestic problems without having to mediate with others, and, despite the initial doubts, they felt free and independent. However, adapting to the gagè dimension was not easy: "do you know what the greatest difficulty was? The first day. On the first day, I just couldn't sleep at night, because I thought: but if this house is now available, it means that those who lived there are dead. And so, the spirit of the dead is here among us, and maybe be doesn't want our presence". It was an absolute novelty: in the camp, death was accompanied by the physical elimination of every object (including the shack) belonging to the deceased. The path of the dead towards eternal rest cannot be hindered by a bridge with earthly life: the dead are only to be forgotten; they are not talked about.

Even inside the house, the Romá stripped the space of all cultural traits. The arrangement of the furniture in the living room was one of the details that surprised me most. They recreated a large central space covered with coloured cushions and rugs that recalled the function of the courtyards of the nomad camp. Each day, I found a different disposition of the house in its appearance and colours. They used to move furniture during the night: this undoubtedly became one of the reasons for quarrels with the neighbourhood. Like in the caravan, the bedroom continued to be the couple's private place: it consisted only of a large wardrobe, a double bed covered with a coloured towel and a series of cushions. The daughter's bed was in the living room, mirroring the dynamics I had already observed in the nomad camp. A substantial difference was the presence of a bathroom inside the domestic space. The presence of bathroom became interesting if thought as a part of a dirt/cleanliness, purity/ impurity dimension, paraphrasing Mary Douglas (1991) in a perception of danger. In order to preserve purity, the use of the bathroom was exclusive for blood relatives and not to

\footnotetext{
${ }^{7}$ The English translation tries to faithfully report the language used by Romá in Italian.
} 
other guests. Despite the presence of services and new appliances such as the washing machine, I saw Svetlana washing clothes several times in a large tub outside the house, in the driveway in front of the door. She told me that she preferred to respect what he had learned at the nomad camp: "the washing machine does not wash as we do. I don't trust it and even if the neighbourbood looks at me amazed, I prefer to wash them like this. It's cleaner". This is a further element that confirms the Romá desire to maintain a sort of continuity with the nomad camp space and dynamics. Finally, the kitchen did not improve the food hygiene of the Romá: they continued to eat at any time, consuming junk food and packaged food bought at the snack machine close to home.

Although the three-year project was planned to last until 2015, it is still ongoing in institutional silence. The attention of the media is no longer focussed on the Roma: the movement in the territory has made their presence less perceptible to the local population. However, the eviction of the camp and housing policies have failed in their inclusive intent. Today families continue to live in strong conditions of social exclusion. Everyone lives outside the city, while nobody lives in Cagliari. Very few nuclear families live in apartments in the municipalities of the vast area around the city. Today Rubi, Svetlana and their two children are living in Quartu, the second largest city in the metropolitan area, confirming the importance of staying close to the gagikani capital built over the last year. The reproduction of illegal camps deserves particular attention: all extended families prefer land to settle, refusing the remote possibility of having a large house. They build the main cabin, and surround it with caravans perfectly respecting Roma spatial ordering. The choice to live on land and not within domestic walls continues to be ignored by institutions. The Tiziana law is still in force and the funds to finance the municipal project continue to be drawn from the protection of nomadism. So, nomadism continues to be considered a Roma cultural trait, but, today, appears to be assigned by non-Roma.

\section{Discussion}

In this paper, I have shown how constructing trust within a Xoraxanè Romá group allowed me to conduct a long lenghty ethnographic fieldwork and to rebuild family ties through the use of space and the practices of recognition in it. According to Goffman (1963), stigmatization is the interpretative key of the Roma's recognition practices through a constant reworked of living spaces linked to their needs and identity boundaries. Since their arrival in Sardinia, Romá have developed strategies of resistance through the willpower to self-determine their everyday life. 
The nomad camp is a segregating externally visible place, whose borders are not recognized by the Romà. They react to exclusion labels and reclaim space through invisible processes of identification on it. The paper showed a reading of the spatial boundaries reconstructed by the Romá: through the rule of patrilocality, the space of the camp is divided into circular courtyards, symbol of sharing and aggregation between groups. The camp space is redesigned according to psychological boundaries dictated by both parental and economic ties between families. The result is a reading of a spatial hierarchy not visible to the external eye but well defined and respected by the group. The camp thus becomes the union of several recognized groups through the construction of courtyards that are usually the symbol of the collaboration of the extended family. Space highlights the solidity of the family organization where authority gradually diminishes with the residential family, parent, relatives and nonrelatives (Piasere 1991). However, within the shared space, the shack or caravan is always the symbol of a couple's intimacy, it is the housing unit of the single nuclear family. From this, it depends that the Romá order is experienced as a meeting of differences (Piasere 1999).

Being forced to stay off the nomad camp takes them further away from the edge of town. Being out of the camp means both losing the hierarchical order established within it, and leaving an urban dimension made up of trust networks built with the local population over the years. Following the fracture of cultural codes not recognized by the Gagé, the Romá identity is built in a liminal space that always passes between visibility and invisibility. Life in apartments makes them invisible to population control: the consequent territorial dispersion causes the disappearance of the hierarchical space of the family knows as "dense relations" (Hannerz 1980) and this disappearance creates fundamental changes in family ties. Furthermore, new physical and cultural barriers caused the loss of relationships based on trust created with health services, assistance network, and, above all, informal economies carried out within the urban area. This territorial dispersion also translates into poor hygiene and housing conditions, persistence of prejudice and racism, poor access to the labour market and high levels of none attendance in schools.

Thus, living roaming becomes a new symbol of recognition (Solimene 2013). Staying close to the 554 ringroad and refusing the home is functional to the new search for an area in which to stop. It means seeking continuity with the nomad camp dimension. This was also observed in the domestic experience of Rubi and Svetlana. Deep cleaning the house by constantly moving the furniture, washing clothes according to the tradition learned in the camp and refusing the comfort of services, concerns a 
dimension of the pure / impure (Douglas 1991) that tries to reconnect them with the camp. Even when they do not reject the domestic dimension, they always find a way to re-establish a continuity with the camp that has also been observed in the use of the rooms.

Local policies have never considered dynamic social organizations into which Roma groups appear and reshape according to the context (Piasere 1991, 1999, 2004). These kinds of policies fail in terms of inclusion and, on the other hand, encourage a careful response of what have often been called the "resistance subcultures" (Hebdige 1979). In this context, degagization confirms the requirement of liveability of a place for a Roma. Housing policies have only confirmed the power of categorising Roma (Pontrandolfo 2018): the labelling of Roma as nomads is used to both develop and legitimise government policy (such as the construction of nomad camps or new housing policies). This reinforces the perception of their nomadism (Brunello 1996, ERRC 2000, Sigona 2003, 2005, OsservAzione 2008, Piasere 2008, pp. 159-196).

\section{References}

Agamben, G. 2005 State of exception, Chicago, University of Chicago Press.

Appadurai, A. 1996 Modernity at large, Minneapolis, MN, University of Minnesota Press.

Aradau, C. et al 2013 Mobility interrogating free movement: Roma acts of European citizenship. In E.F. Isin and M. Saward (eds), Enacting European Citizenship, pp. 132-154. New York, NY: Cambridge University Press.

Bauman, Z. 2003 Intervista sull'identità, Rome-Bari, Laterza.

Becker, H.S. 1987 Outsiders. Saggi di sociologia della devianza (1963), Edizioni Gruppo Abele, Turin

Brunello, P. 1996 Cartelli per chiedere la carità (Mestre e Venezia, 1993-1995), in Italia romaní, vol. I, Piasere L, Rome, Cisu, pp. 263-276.

Colombo, E. 2007 Decostruire l'identità: individuazione e identificazione in un mondo globale, in «Culture: Annali del Dipartimento di lingue e culture contemporanee, Faculty of Political Science Univerisity of Milan

Cozannet, F. 1990 Gli Zingari: Miti e usanze religiose, Milan, Mondadori.

Cuche, D. 1996 La notion de culture dans les sciences socials, Paris, La Découverte.

Dal Lago, A. 2004 Non - persone, l'esclusione dei migranti in una società globale, Milan, Feltrinelli.

Douglas, M. 1991 Come percepiamo il pericolo (1985), Milano, Feltrinelli.

FRA2009 Data in focus report: The Roma. Vienna: European Union Agency for Fundamental Rights.

Goffman, E. 1963 Stigma: l'identità negata, Milano, Giuffré.

Grill, J.2012 Going up to England': Exploring mobilities among Roma from Eastern Slovakia in Journal of Ethnic and Migration Studies, 38(8), 1269-1287.

ERRC, 2000 Il paese dei campi: la segregazione razziale dei rom in Italia, Rome, Manifesto Libri.

Fabietti, U. 2004 Elementi di antropologia culturale, Milan, Mondadori

Fassin, D. 2001 The Biopolitics of Otherness. Undocumented Foreigners and Racial Discrimination in French Public Debate in Anthropology Today 17 (1): 3-7. 
Hannerz, U. 1980 Exploring the city: Inquiries toward an urban anthropology, New York, Columbia University Press

Hebdige, D. 1979 Subculture. The meaning of style, London 1979

Herzfeld, M. 1987 Anthropology Through the Looking Glass: Critical Ethnography in the Margins of Europe, Cambridge: Cambridge University Press.

Herzfeld, M. 2001 Anthropology: Theorical practice in culture and society, Cambridge, Blackwell.

Liégeois J.P1987 Zingari e viaggianti, Roma, Lacio Drom

Maneri, M. 2018 Media hypes, moral panics, and the ambiguous nature of facts in Vasterman, P. (ed.) Media Hype to Twitter Storm. News Explosions and Their Impact on Issues, Crises, and Public Opinion, Amsterdam, University Press.

Meneghini, A.M. and F. Fattori 2016 Distinzioni e sovrapposizioni tra Romeni, Rom e Rom Romeni: un'indagine psicosociale. In S. Pontrandolfo and L. Piasere (eds), Italia Romaní, Le Migrazioni dei Rom Romeni in Italia, vol. VI, pp. 81-108. Rome, CISU.

Nicolae, V. 2006 Towards a definition of Anti-Gypsysm, www.ergonetwork.org/anti gypsysm.htm

Parker, O. 2012 Roma and the politics of EU citizenship in France: Everyday security and resistance in JCMS: Journal of Common Market Studies., 50(3), 475-491.

Pew Research Centre 2014 Afragile rebound for EU image on eve of European Parliament elections. Report. Online at: http://www.pewglobal.org/ les/2014/05/20140-51-2_ Pew-Global-AttitudesEuropean-Union.pdf

Piasere, L. 1991 Popoli delle discariche, Rome, Cisu

Piasere, L. 1999 Un mondo di mondi. Antropologia delle culture rom, Napoli, L'ancora

Piasere, L. 2004 I rom d'Europa, Rome-Bari, Laterza.

Piasere, L. 2015 L'antiziganismo, Macerata, Quodlibet Studio

Pontrandolfo, S 2018 Roma 'acts of citizenship': negotiating categories and housing solutions in NOMADIC PEOPLES 22, 1, pp. 83-103.

Pontrandolfo, S. , Solimene, M. 2018 Introduction in NOMADIC PEOPLES 22, 1, pp. 10-26.

Taguieff, P.A. 1987 La forza del pregiudizio. Saggio sul razzismo e sull'antirazzismo, Bologna, Il Mulino.

Scotti G, 1978 Zingaro, chi sei?, Napoli, Ferrero.

Sigona, N. 2013 Campzenship: Rethinking the camp as a political space, International Symposium Within and beyond citizenship. Lived experiences of contemporary membership, Oxford, 11-12 April 2013.

Solimene, M. 2013 Undressing the gağe dressed in state garb. Bosnian Xoraxané Romá face to face with the Italian authorities. Romani Studies, 23(2): 23-48.

Solimene, M. 2014 The rootedness of a community of Xoraxané Romá in Rome. In I. Clough Marinaro \& B. Thomassen (Eds.), Global Rome. Changing Faces of the Eternal City (pp. 129-42). Bloomington (IN): Indiana University Press.

Thompson, T.W. 1923 The Social Polity of the English Gypsies, in Journal of the Gypsy Lore Society, 3rd series, II, pp 113-139

Taylor, D. B. 1999 Begging for change: A social ecological study of aggressive panhandling and social control in Los Angeles. Ph.D. diss., Criminology, Law and Society Program, Univ. of California, Irvine.

Tosi Cambini, S. 2012 Antiriganismo: Strumenti Interpretativi e Fenomenologia Contemporanea, in Anuac 1 (1): $17-23$.

van Baar, H. 2014 The Emergence of a Reasonable Anti-Gypsyism in Europe, in When Stereotype Meets Prejudice: Antiziganism in European Societies, ed. T. Agarin. Stuttgart: Ibidem. pp. 27-44. 
van Baar, H. 2017 Contained mobility and the racialization of poverty in Europe: The Roma at the developmentsecurity nexus, in Social Identities, 24, 1-17.

Williams, P. 2011 L'Ethnologie des Tsiganes, in Des Tsiganes en Europe, ed. M. Stewart and P. Williams. Paris: Éditions de la Maison des Sciences de l'Homme. pp. 9-32.

Wieviorka, M. 1998 Le Racism. Une Introduction, Paris, Découvert \& Syros.

Wimmer. A, 1997 Explaining Xenophobia and Racism. A Critical Review of Current Research Approaches, in Ethnic and Racial Studies 20 (1): 17-41.

Zatta D. J. 1988 Gli zingari, i roma, una cultura ai confini, Padova, Cidi Triveneto. 